\title{
Effect of adding mannan-oligosaccharide to the diet on the performance, weight of digestive tract segments, and caecal digesta parameters in young turkeys
}

\author{
J. Juśkiewicz ${ }^{1}$, Z. Zduńczyk ${ }^{1}$ and J. Jankowski² \\ ${ }^{1}$ Institute of Animal Reproduction and Food Research, Polish Academy of Sciences, \\ Division of Food Science \\ Tuwima 10, 10-747 Olsztyn, Poland \\ ${ }^{2}$ Department of Poultry Science, University of Warmia and Mazury in Olsztyn \\ Oczapowskiego 5, 10-718 Olsztyn, Poland
}

(Received 1 March 2002; revised version 12 November 2002; accepted 20 December 2002)

\begin{abstract}
Turkey chickens were fed for 4 weeks with starter diets containing $0.1,0.2$ and $0.4 \%$ mannan-oligosaccharide (groups MOS-0.1, MOS-0.2, and MOS-0.4, respectively) and a control diet without oligosaccharides. Supplementation of diets with mannan-oligosaccharide had no statistically significant influence on growth or relative weight of the stomach, small intestine or colon. MOS had a different influence on the weight of the caeca and caecal digesta parameters. Gradually increasing mannan supplementation to the diet lowered caecal tissue and digesta weight compared with the control group. The dry matter of caecal digesta was unaffected by the added mannan, the ammonia and nitrogen contents were reduced, but the $\mathrm{pH}$ of the caecal content was significantly greater after mannan supplementation than in the control group. Compared with the control diet, mannan intake caused a slight increase in short-chain fatty acid (SCFA) concentrations in the caeca, especially of propionate, but the caeca SCFA pool (as a consequence of the lower ceacal content) was significantly decreased in groups MOS-0.2 and MOS-0.4. In turkeys fed mannan-diets a decrease in the bacterial glycolytic activity in the caecal digesta was observed, especially in $\alpha$-glucosidase, $\alpha$-galactosidase and $\beta$-galactosidase activities. A beneficial decrease in $\beta$-glucuronidase activity was observed only with the highest amount of MOS in the diet $(0.4 \%)$.
\end{abstract}

KEY WORDS: caecum, glycolytic activity, mannan-oligosaccharide, SCFA, turkey 


\section{INTRODUCTION}

Some studies have reported that mannan-oligosaccharide (MOS) represents a natural biological alternative to feed antibiotics and is considered beneficial to animals (Newman, 1994; Iji and Tivey, 1998). MOS is derived from the cell walls of yeast Saccharomyces cerevisiae. The beneficial properties of several oligosaccharides, such as fructo- or gluco-oligosaccharides, are well known because they are used as substrates by potentially beneficial intestinal bacteria, but not by pathogenic or detrimental microorganisms (Monsan and Paul, 1995). MOS has a direct effect on pathogens such as Escherichia coli and Salmonella by binding to the lectin receptors on the surface of the cell walls of pathogenic bacteria. Once this occurs, the pathogen cannot attach itself to the receptors on the cell membrane of the intestinal epithelium and is flushed from the animal with the excreta (Newman, 1994). The second mechanism of MOS action is through the immune system. It has been observed that MOS markedly increased the concentrations of Ig A and Ig G antibodies in the intestines (Newman, 1994; Savage and Zakrzewska, 1996). That action is important because about $70 \%$ of the immune cells are located in the intestine and Ig A antibodies prevent bacteria and viruses from attaching to the intestinal epithelia. Further studies will, however, be necessary to better understand the biological responses to MOS and to identify other physiological effects that may occur after MOS-supplementation to the diet. Because the main action of mannan-oligosaccharide is associated with the gastrointestinal tract, the purpose of our study was to estimate the caecal environmental changes after various mannan-oligosaccharide supplementations to the diet for young turkey-chickens.

\section{MATERIAL AND METHODS}

\section{Animals and diets}

The experiment was conducted on 40 three-day-old BUT-9 turkey chickens randomly allocated to four groups. The birds were kept in wire cages, housed under standard conditions and fed four weeks ad libitum with mash basal diet (Table 1), supplemented with $0.4 \%$ wheat (control group), $0.3 \%$ wheat and $0.1 \%$ mannanoligosaccharide (group MOS- 0.1 ), $0.2 \%$ wheat and $0.2 \%$ mannan-oligosaccharide (group MOS-0.2) or $0.4 \%$ of mannan-oligosaccharide (group MOS-0.4). The nutritional value of the basal diet was formulated to meet nutritional requirements (NRC, 1994) for the starter period. Mannan-oligosaccharide (BioMos, Alltech Inc.) was derived from the cell walls of the yeast, Saccharomyces cerevisiae. 
TABLE 1

Formula and calculated chemical composition and nutritive value of basal diet

\begin{tabular}{lclc}
\hline Components & $\%$ & Calculated chemical composition & \\
\hline Ground wheat & 15.60 & ME, MJ $/ \mathrm{kg}$ & 11.70 \\
Maize & 30.00 & Crude protein, \% & 27.89 \\
Soyabean meal & 41.00 & Crude fibre, \% & 3.35 \\
Meat-and-bone meal & 8.00 & Lys, g/kg & 16.0 \\
Soyabean oil & 2.50 & Met + Cys, g/kg & 10.5 \\
Mineral sources $^{2}$ & 1.54 & $\mathrm{Ca}, \mathrm{g} / \mathrm{kg}$ & 12.5 \\
Amino acids $^{3}$ & 0.36 & $\mathrm{P}$ available, $\mathrm{g} / \mathrm{kg}$ & 6.0 \\
Trace mineral and vitamin $_{\text {premix }}{ }^{4}$ & 1.00 & & \\
\hline
\end{tabular}

${ }^{1}$ nutrients of diets calculated according to recommendation of NRC (1994)

${ }^{2} \mathrm{NaCl}-0.1 \%, \mathrm{NaHCO}_{3}-0.10 \%$, monocalcium phosphate - $0.71 \%$, limestone $0.63 \%$

${ }^{3}$ DL-methionine - $0.21 \%$, L-lysine - $0.15 \%$

${ }^{4}$ in $1 \mathrm{~kg}$ of diet: vit. A 15,000 IU; vit. $\mathrm{D}_{3} 4,500 \mathrm{IU}$; cit. E $50 \mathrm{mg}$; vit. $\mathrm{K}_{3} 2.5 \mathrm{mg}$; vit. $\mathrm{B}_{1} 3.5 \mathrm{mg}$; vit. $\mathrm{B}_{2} 10 \mathrm{mg}$; vit. $\mathrm{B}_{6} 6 \mathrm{mg}$; vit. $\mathrm{B}_{12} 0.03 \mathrm{mg}$; folic acid $2 \mathrm{mg}$; biotin $0.36 \mathrm{mg}$; niacin $75 \mathrm{mg}$; panthotenic acid $21 \mathrm{mg}$; choline 600 mg; Mn 150 mg; Zn 90 mg; Fe 60 mg; Cu 15 mg; J 1 mg; Se 0.3 mg; Diclazuril $1 \mathrm{mg}$, Flawofosfolipol $5 \mathrm{mg}$ and Avizyme 1300 - $1 \mathrm{~g}$

\section{Sample procedures}

After 4 weeks of feeding, the birds were weighed and killed according to the recommendations for euthanasia of experimental animals (Close et al., 1997). The main parts of the digestive tract (stomach, small intestine, caeca, colon) were removed and weighed. Caecal $\mathrm{pH}$ was measured using a microelectrode and $\mathrm{pH} / \mathrm{ION}$ meter (model 301, Hanna Instruments). Samples of caecal contents were transferred to microfuge tubes which were immediately stored at $-40^{\circ} \mathrm{C}$. The caecum wall was flushed clean with ice-cold saline, blotted on filter paper and weighed (caecal wall weight). The same was done with the stomach, small intestine and colon.

\section{Analysis of caecal content}

Dry matter of the caecal digesta was determined by the difference between wet weight and dry weight on aliquots of caecal contents that were dried to a constant weight. Ammonia extracted and trapped in a solution of boric acid was determined by direct titration with sulphuric acid (according to the standard Conway method). The nitrogen content in the caecal digesta was determined according to the Kjeldahl method. The protein content was determined by a colorimetric method according to Lowry (1951) using the Folin-Ciocolteu phenol reagent. The concentration of shortchain fatty acids (SCFA) in the caecal content was measured by gas chromatography (Shimadzu GC-14A with a glass column $2.5 \mathrm{~m}$ x $2.6 \mathrm{~mm}$, containing 10\% SP-1200/ 
$1 \% \mathrm{H}_{3} \mathrm{PO}_{4}$ on $80 / 100$ Chromosorb W AW, column temperature $110^{\circ} \mathrm{C}$, detector FID temperature $180^{\circ} \mathrm{C}$, injector temperature $195^{\circ} \mathrm{C}$ ). The caecal digesta was weighed, mixed with $0.2 \mathrm{~mL}$ formic acid (internal standard), diluted with deionised water and centrifuged at $10000 \mathrm{xg}$ for $5 \mathrm{~min}$. The supernatant was decanted for injection in the gas chromatograph.

Glycolytic activity in the caecal digesta was measured by the rate of release of p- or o- nitrophenol from their p- or o-nitrophenylglucosides (Djouzi and Andrieux, 1997). The reaction mixture contained $0.3 \mathrm{~mL}$ substrate solution $(5 \mathrm{mM})$ and 0.2 $\mathrm{mL}$ of a caecal sample diluted 1:10 (v/v) in a phosphate buffer $(\mathrm{pH} 7.0,0.1$ $\mathrm{Mol} / \mathrm{L}$ ). Incubation was carried out at $37^{\circ} \mathrm{C}$ and the p-nitrophenol concentration was measured as the optical absorbance at $400 \mathrm{~nm}$ and at $420 \mathrm{~nm}$ (o-nitrophenol concentration) after addition of $2.5 \mathrm{~mL} 0.25 \mathrm{M}$ sodium carbonate. Enzymatic activity was expressed as $\mu \mathrm{mol}$ product formed per min (IU) per g caecal content or per $\mathrm{g}$ $10^{-2}$ protein in the caecal sample.

\section{Statistical analysis}

The results of the experiment were analysed using the one-way ANOVA test, and significant differences between groups were determined by Duncan's multiple range test. Differences were considered significant at $\mathrm{P} \leq 0.05$ and $\mathrm{P} \leq 0.01$.

\section{RESULTS}

Supplementation of diets with mannan-oligosaccharide had no statistically significant influence on the turkeys' growth, diet intake or feed efficiency ratio, however, in the MOS-groups a tendency towards higher diet intake and growth was observed (Table 2). Turkeys fed the control diet and the MOS-groups had a similar relative weight of the stomach, small intestine and colon. Supplementation of diet with MOS had a different influence on the weight of caeca and caecal digesta parameters. The relative tissue weight of the caeca was higher $(\mathrm{P} \leq 0.05)$ in turkeys fed the diet containing $0.1 \%$ MOS compared with birds fed the diet containing $0.4 \%$ MOS. The other treatments were intermediate. Turkeys fed the control diet had a higher $(\mathrm{P} \leq 0.05)$ relative content of caecal digesta compared with the birds fed the MOS- $0.2 \%$ and MOS- $0.4 \%$ diets. Dry matter of the digesta was statistically unaffected by treatments. The $\mathrm{pH}$ of the caecal digesta was higher $(\mathrm{P} \leq 0.05)$ in turkeys consuming the MOS- 0.2 and MOS- $0.4 \%$ diets compared with the control group. The concentrations of ammonia and nitrogen, as well as the protein content in the caecal digesta (determined by Lowry's method and expressed as $\mathrm{mg} / 100 \mathrm{~g}$ $\mathrm{BW}$ ) were lower in the turkeys fed MOS-supplemented diets in comparison with the control diet. 
TABLE 2

Caecal digesta parameters in young turkeys

\begin{tabular}{|c|c|c|c|c|c|}
\hline & \multicolumn{4}{|c|}{ Diets } & \multirow{2}{*}{ SEM } \\
\hline & Control & MOS-0.1 & MOS-0.2 & MOS-0.4 & \\
\hline Initial body weight, $\mathrm{g}$ & 59 & 61 & 60 & 60 & 0.43 \\
\hline Diet intake, $\mathrm{g} / 30$ days & 1133 & 1180 & 1235 & 1203 & - \\
\hline Body weight gain, $g / 30$ days & 692 & 682 & 728 & 715 & 7.92 \\
\hline Feed efficiency ratio, $\mathrm{g} / \mathrm{kg}$ BW & 1637 & 1730 & 1696 & 1683 & - \\
\hline \multicolumn{6}{|l|}{ Weight of gastrointestinal tract } \\
\hline stomach, g/100 g BW & 2.31 & 2.23 & 2.04 & 2.16 & 0.03 \\
\hline small intestine, $\mathrm{g} / 100 \mathrm{~g} \mathrm{BW}$ & 3.20 & 3.07 & 2.93 & 3.01 & 0.03 \\
\hline caeca, g/100 g BW & $0.71^{\mathrm{ab}}$ & $0.81^{\mathrm{a}}$ & $0.74^{\mathrm{ab}}$ & $0.66^{\mathrm{b}}$ & 0.02 \\
\hline colon, g/100 g BW & 0.43 & 0.41 & 0.36 & 0.38 & 0.01 \\
\hline \multicolumn{6}{|l|}{ Caecal digesta parameters } \\
\hline caecal content, g/100g BW & $0.81^{\mathrm{a}}$ & $0.76^{\mathrm{ab}}$ & $0.63^{\mathrm{b}}$ & $0.64^{\mathrm{b}}$ & 0.04 \\
\hline $\mathrm{DM}, \%$ & 17.6 & 16.1 & 17.5 & 17.2 & 0.33 \\
\hline $\mathrm{pH}$ & $6.26^{\mathrm{b}}$ & $6.52^{\mathrm{a}}$ & $6.56^{\mathrm{a}}$ & $6.41^{\mathrm{ab}}$ & 0.05 \\
\hline nitrogen, $\%$ & $1.81^{\mathrm{a}}$ & $1.62^{\mathrm{b}}$ & $1.73^{\mathrm{ab}}$ & $1.71^{\mathrm{ab}}$ & 0.03 \\
\hline ammonia, $\mathrm{mg} / \mathrm{g}$ digesta & $0.66^{\mathrm{a}}$ & $0.58^{\mathrm{b}}$ & $0.57^{\mathrm{b}}$ & $0.55^{\mathrm{b}}$ & 0.02 \\
\hline ammonia, mg/100 g BW & $0.53^{\mathrm{A}}$ & $0.44^{\mathrm{B}}$ & $0.36^{\mathrm{C}}$ & $0.35^{\mathrm{C}}$ & 0.02 \\
\hline protein $^{1}, \mathrm{mg} / 100 \mathrm{~g} \mathrm{BW}$ & $0.41^{\mathrm{A}}$ & $0.33^{\mathrm{B}}$ & $0.31^{\mathrm{B}}$ & $0.31^{\mathrm{B}}$ & 0.01 \\
\hline
\end{tabular}

${ }^{1}$ according to the Lowry's method

ab $\mathrm{P} \leq 0.05 ;{ }^{\mathrm{AB}} \mathrm{P} \leq 0.01$

As shown in Table 3, in general, including mannan-oligosaccharide in the diet caused a decrease in bacterial glycolytic activity in the caeca, especially in $\alpha$-glucosidase, $\alpha$-galactosidase and $\beta$-galactosidase activities. A decrease in $\beta$ glucosidase activity was found only in the MOS- $0.1 \%$ group. The $\beta$-glucuronidase activity in the caecal digesta significantly decreased in the MOS- $0.4 \%$ group when compared with the control. The decrease was not significant in the MOS- 0.1 and MOS- $0.2 \%$ groups.

The caecal SCFA pool, expressed as $\mu \mathrm{mol} / 100 \mathrm{~g} \mathrm{BW}$, was significantly altered due to mannan treatments (Table 4). It was higher $(\mathrm{P} \leq 0.05)$ in birds consuming control and MOS- $0.1 \%$ diets compared with the other treatments (MOS- 0.2 and MOS- $-0.4 \%)$. On the whole, the SCFA in the MOS-groups consisted of acetate $(79 \%)$, propionate $(5-6 \%)$, butyrate (11\%) and a small amount of valerate. Compared with the control group, MOS supplementation did not markedly alter the ratios of these SCFA, only the propionate concentration in the MOS- $0.4 \%$ group was significantly $(\mathrm{P} \leq 0.05)$ higher than in the control group. 
TABLE 3

Glycolytic activity in caecal digesta

\begin{tabular}{|c|c|c|c|c|c|c|}
\hline \multirow{2}{*}{ Enzymes } & \multirow{2}{*}{ Indices } & \multicolumn{4}{|c|}{ Diet } & \multirow{2}{*}{ SEM } \\
\hline & & Control & MOS-0.1 & MOS-0.2 & MOS-0.4 & \\
\hline \multirow{2}{*}{$\alpha$-glucosidase } & $\mathrm{U} / \mathrm{g}$ fresh digesta & $1.94^{\mathrm{a}}$ & $1.45^{\mathrm{b}}$ & $1.39^{\mathrm{b}}$ & $1.34^{\mathrm{b}}$ & 0.09 \\
\hline & $\mathrm{U} / \mathrm{g} 10^{-2}$ protein & $0.76^{\mathrm{a}}$ & $0.68^{\mathrm{ab}}$ & $0.56^{\mathrm{b}}$ & $0.56^{\mathrm{b}}$ & 0.03 \\
\hline \multirow{2}{*}{$\beta$-glucosidase } & $\mathrm{U} / \mathrm{g}$ fresh digesta & $0.32^{\mathrm{a}}$ & $0.16^{\mathrm{b}}$ & $0.34^{\mathrm{a}}$ & $0.35^{\mathrm{a}}$ & 0.02 \\
\hline & U/g $10^{-2}$ protein & $0.13^{\mathrm{a}}$ & $0.08^{\mathrm{b}}$ & $0.15^{\mathrm{a}}$ & $0.14^{\mathrm{a}}$ & 0.01 \\
\hline \multirow{2}{*}{$\alpha$-galactosidase } & $\mathrm{U} / \mathrm{g}$ fresh digesta & $1.51^{\mathrm{ab}}$ & $1.69^{\mathrm{a}}$ & $0.90^{\mathrm{b}}$ & $0.82^{\mathrm{b}}$ & 0.14 \\
\hline & $\mathrm{U} / \mathrm{g} 10^{-2}$ protein & $0.60^{\mathrm{ABa}}$ & $0.66^{\mathrm{Aa}}$ & $0.36^{\mathrm{Bb}}$ & $0.34^{\mathrm{Bb}}$ & 0.04 \\
\hline \multirow{2}{*}{$\beta$-galactosidase } & $\mathrm{U} / \mathrm{g}$ fresh digesta & $4.17^{\mathrm{a}}$ & $3.02^{\mathrm{b}}$ & $3.44^{\mathrm{b}}$ & $3.25^{\mathrm{b}}$ & 0.22 \\
\hline & $\mathrm{U} / \mathrm{g} 10^{-2}$ protein & 1.65 & 1.42 & 1.47 & 1.35 & 0.09 \\
\hline \multirow{2}{*}{$\beta$-glucuronidase } & $\mathrm{U} / \mathrm{g}$ fresh digesta & $0.47^{\mathrm{A}}$ & $0.37^{\mathrm{AB}}$ & $0.36^{\mathrm{AB}}$ & $0.26^{\mathrm{B}}$ & 0.03 \\
\hline & $\mathrm{U} / \mathrm{g} 10^{-2}$ protein & $0.18^{\mathrm{a}}$ & $0.18^{\mathrm{a}}$ & $0.14^{\mathrm{ab}}$ & $0.11^{\mathrm{b}}$ & 0.01 \\
\hline
\end{tabular}

${ }_{\mathrm{a}, \mathrm{b}}$ values within each row with the same superscript are not different at $\mathrm{P} \leq 0.05$

${ }^{A, B}$ values within each row with the same superscript are not different at $\mathrm{P} \leq 0.01$

TABLE 4

Short chain fatty acids (SCFA) content $(\mu \mathrm{mol} / 100 \mathrm{~g} \mathrm{BW})$ and concentration $(\mu \mathrm{mol} / \mathrm{g})$ in the caecal digesta of turkeys

\begin{tabular}{|c|c|c|c|c|c|}
\hline \multirow{2}{*}{ Indices } & \multicolumn{4}{|c|}{ Diet } & \multirow{2}{*}{ SEM } \\
\hline & Control & MOS-0.1 & MOS-0.2 & MOS-0.4 & \\
\hline Content of SCFA & $96.45^{\mathrm{a}}$ & $96.88^{\mathrm{a}}$ & $82.53^{\mathrm{b}}$ & $81.46^{\mathrm{b}}$ & 2.85 \\
\hline SCFA concentration & 119.07 & 127.47 & 131.00 & 127.28 & 3.05 \\
\hline acetate & 93.01 & 100.76 & 103.94 & 99.94 & 4.06 \\
\hline propionate & $5.56^{\mathrm{b}}$ & $6.64^{\mathrm{ab}}$ & $6.81^{\mathrm{ab}}$ & $8.08^{\mathrm{a}}$ & 0.33 \\
\hline isobutyrate & 1.92 & 2.06 & 1.92 & 1.72 & 0.11 \\
\hline butyrate & 15.11 & 14.45 & 14.69 & 14.24 & 0.43 \\
\hline isovalerate & 2.02 & 1.84 & 1.85 & 1.63 & 0.12 \\
\hline valerate & 1.45 & 1.72 & 1.79 & 1.67 & 0.07 \\
\hline $\mathrm{C}_{2}: \mathrm{C}_{3}: \mathrm{C}_{4}$ profile $^{1}$ & $78: 5: 13$ & $79: 5: 11$ & $79: 5: 11$ & $79: 6: 11$ & \\
\hline
\end{tabular}

${ }^{1} \mu \mathrm{mol} / 100 \mu \mathrm{mol}$ total SCFA

${ }^{\mathrm{ab}}$ values within each row with the same superscript are not different at $\mathrm{P} \leq 0.05$

\section{DISCUSSION}

The literature describing the effects of mannan-oligosaccharides in poultry is scarce (Savage and Zakrzewska, 1996; Iji and Tivey, 1998). These authors have reported preliminary results of bird response to MOS-treatment. They did not 
give much information on caecal parameters, but focused attention to an immunostimulatory response and an improvement in the body weight gain associated with mannan-oligosaccharides. The recommended level of MOS in the diet was estimated at $1.0 \mathrm{~g} / \mathrm{kg}$. In the presented study supplementation of diets with mannanoligosaccharide was higher $(1,2$ and $4 \mathrm{~g} / \mathrm{kg}$ but the period of the experiment was relatively short-only 30 days). Probably for this reason the influence of MOS on diet intake, bird growth and feed utilization was lacking.

It has been reported that providing mannan-oligosaccharide in a diet could improve the health conditions in the gastrointestinal tract (Newman, 1994). In this study, attention was paid to the development of the caeca. The relative tissue weight of the caeca was found to be significantly higher in turkeys fed the MOS- $0.1 \%$ diet compared to that of turkeys fed the diet containing $0.4 \%$ MOS. Short-chain fatty acids (SCFAs), the main products of caecal fermentation, are responsible for normalizing gut cell proliferation (Frankel et al., 1994). Sakata (1987) demonstrated in rats that intraluminally infused SCFA accelerated the crypt cell production rate and increased the gut-wall mass. The stimulation was most observable with butyrate. The site of bacterial fermentation in birds, as well as in rats, is mainly the caeca (Annison et al., 1968). Some research has suggested that when feeding oligosaccharides of various fermentability, the caecal SCFA pool appears to be a more accurate reflection of caecal fermentation than SCFA concentration (Berggren et al., 1993; Campbell et al., 1997). Other research has shown that different amounts of the same oligosaccharide added to the diet correlated better with the caecal pool of rats than with the caecal concentration of SCFA (Levrat et al., 1991; Remesy et al., 1992). In the presented study, the caecal SCFA pool was significantly altered by mannan added to the diets. The higher the amounts of mannan-oligosaccharide that were added to diet, the smaller the caecal SCFA pool was found, while caecal SCFA concentrations were not changed due to mannan treatments. Adverse effect of MOS on caecal weight and caecal wall weight were observed compared with other results (Younes et al., 1995; Campbell et al., 1997), which have demonstrated a higher caecal tissue weight caused by some oligosaccharides, such as fructooligosaccharide, xylooligosaccharide and oligofructose, compared with control diets (with or without cellulose).

With MOS treatments the protein pools in the caecal digesta were significantly lower than in the control group. This, as well as a decrease in the bacterial glycolytic activity found in the caeca in all MOS-groups, suggested lowering of the activity of caecal microflora in birds fed the MOS-diets compared with control turkeys.

In the presented study, some diverse consequences for caecum health were observed after MOS supplementation to the diets. Rowland (1988) suggested that several bacterial enzymes, such as $\beta$-glucuronidase, nitroreductase, as well as $\beta$ glucosidase may play a role in colon carcinogenesis by converting pre-carcinogens to proximal carcinogens. A significant decrease was found in $\beta$-glucuronidase 
activity in the caecal digesta of turkeys given mannan-supplementation, but $\beta$ glucosidase activity was unaffected except for the MOS- $0.1 \%$ group. It should be noted that an increase in the $\beta$-glucosidase activity is more ambiguous because this hydrolytic activity is responsible both for the generation of toxins (Mallet and Rowland, 1988), and for the production of bacterial glucoside derivatives that are assumed to be responsible for protection against chemically-induced cancer (Rowland and Tanaka, 1993). Other caecal physiological parameters such as $\mathrm{pH}$ and ammonia are considered to be risk factors for hind gut cancer development (Sako et al., 1999). In the presented experiment, on the one hand a small caecal $\mathrm{pH}$ increase was found in the MOS-groups compared to the control group, on the other hand, the level of ammonia in the MOS-groups was significantly reduced. In another experiment (Juśkiewicz et al., 2002), we found that supplementation of diets with fructo-oligosaccharides and inulin brought similar results as than addition of mannan-oligosaccharides to the diet.

\section{CONCLUSIONS}

In conclusion, supplementation of turkey diets with the mannan-oligosaccharide considerably changed caecal metabolism. Some positive effects of adding MOS to the diet were found, such as lowering the ammonia concentration and decreasing $\beta$-glucuronidase activity in the caecal digesta, as well as some negative effects, including decreased bacterial glycolytic activity and raised $\mathrm{pH}$ in the caeca. Further studies are necessary to establish the precise relationship between the mannanoligosaccharide treatment and the health status of birds.

\section{REFERENCES}

Annison E.F., Hill K.J., Kenworthy R.C., 1968. Volatile fatty acids in the digestive tract of the fowl. Brit. J. Nutr. 22, 207-216

Berggren A., Bjorck I.M.E., Margareta E., Nyman G.L., Eggum B.O., 1993. Short-chain fatty acid content and $\mathrm{pH}$ in caecum of rats given various sources of carbohydrates. J. Sci. Food Agr. 63, 397-406

Campbell J.M., Fahey G.C., Wolf B.W., 1997. Selected indigestible oligosaccharides affect large bowel mass, caecal and fecal short-chain fatty acids, $\mathrm{pH}$ and microflora in rats. J. Nutr. 127, 130-136

Close B., Banister K., Baumans V., Bernoth E-M., Bromage N., Bunyan J., Erhardt W., Flecknell P., Gregory N., Hackbarth H., Morton D., Warwick C., 1997. Recommendations for euthanasia of experimental animals: Part 2. Lab. Animals 31, 1-32

Djouzi Z., Andrieux C., 1997. Compared effects of three oligosaccharides on metabolism of intestinal microflora in rats inoculated with a human faecal flora. Brit. J. Nutr. 78, 313-324 
Frankel W.L., Zhang W., Singh A., Klurfeld D.M., Don S., Sakata T., Modlin I., Rombeau J.L., 1994. Mediation of the trophic effects of short-chain fatty acids on the rat jejunum and colon. Gastroenterology 106, 375-380

Juśkiewicz J., Zduńczyk Z., Jankowski J., Król B., 2002. Caecal metabolism in young turkeys fed diets supplemented with oligosaccharides. Arch. Geflügelk. 66, 206-210

Iji P.A., Tivey D.R., 1998. Natural and synthetic oligosaccharides in broiler chicken nutrition. World Poultry Sci. J. 54, 129-143

Levrat M.A., Remesy C., Demigne C., 1991. High propionic acid fermentations and mineral accumulation in the caecum of rats adapted to different levels of inulin. J. Nutr. 121, 17301737.

Lowry O.H., Rosebrough N.J., Farr A.L., Randall R.J., 1951. Protein measurement with the Folin phenol reagent. J. Biol. Chem. 193, 265-275

Mallet A.K., Rowland I.R., 1988. Factors affecting the gut microflora. In: Role of the Gut Flora in Toxicity and Cancer. Academic Press, London, pp. 347-382

Monsan P.F., Paul F., 1995. Oligosaccharide feed additives. In: R.J. Wallace, A. Chesson (Editors). Biotechnology in Animal Feeds and Feeding. Weinheim and New York, pp. 233-245

National Research Council, Nutrient Requirements of Poultry, 1994. 9th Edition. National Academy Press, Washington, DC

Newman K.E., 1994. Mannan-oligosaccharides: natural polymers with significant impact on the gastrointestinal microflora and the immune system. In: T.P. Lyons, K.A. Jacques (Editors). Biotechnology in the Feed Industry. Nottingham University Press, pp. 167-175

Remesy C., Behr S.R., Levrat M.A., Demigne C., 1992. Fiber fermentability in the rat caecum and its physiological consequences. Nutr. Res. 12, 1235-1244

Rowland I.R., 1988. Interactions in the gut microflora and the host in toxicology. Toxicol. Pathol. $16,147-153$

Rowland I.R., Tanaka R., 1993. The effects of transgalactosylated oligosaccharides on gut flora metabolism in rats associated with human faecal microflora. J. Appl. Bacteriol. 74, 667-674

Sakata T., 1987. Stimulatory effect of short-chain fatty acids on epithelial cell proliferation in the rat intestine: a possible explanation for trophic effects of fermentable fiber, gut microbes and luminal trophic factor. Brit. J. Nutr. 58, 95-103

Sako T., Matsumoto K., Tanaka R., 1999. Recent progress on research and applications of nondigestible galacto-oligosaccharides. Int. Dairy J. 9, 69-80

Savage T.F., Zakrzewska E.I., 1997. The performance of male turkeys fed a starter diet containing a mannan oligosaccharide. Zoot. Int. 20, 30-32

Younes H., Garleb K., Behr S., Remesy C., Demigne C., 1995. Fermentable fibers or oligosaccharides reduce urinary nitrogen excretion by increasing urea disposal in the rat caecum. J. Nutr. 125, 1010-1016 


\section{STRESZCZENIE}

\section{Wpływ dodatku oligosacharydu mannanu do diety na rozwój, ciężar poszczególnych odcinków przewodu pokarmowego i skład treści jelita ślepego młodych indyków}

Pisklęta indycze żywiono przez 4 tygodnie dietami typu „starter” zawierającymi 0,1;0,2 lub $0,4 \%$ dodatek oligosacharydu mannanu (grupy MOS-0.1, MOS-0.2, MOS-0.4, odpowiednio) oraz dietą kontrolną bez dodatku mannanu. Badano wpływ dodatku mannanu na przemiany w jelitach ślepych indyków. Wzrost zawartości mannanu w diecie spowodował zmniejszenie masy tkanki jelit ślepych oraz masy treści jelitowej w porównaniu z grupą kontrolną. Dodatek mammanu nie wpływał na zawartość suchej masy w treści jelit ślepych, natomiast $\mathrm{pH}$ treści było istotnie wyższe niż w grupie kontrolnej. Ilość azotu ogólnego i amoniaku w treści jelitowej zmniejszyła się po dodaniu do diet mannanu. Dodatek MOS zwiększał nieznacznie koncentrację LKT w jelitach ślepych (głównie propionianów), chociaż całkowita ilość tych kwasów (wskutek zmniejszenia ilości treści pokarmowej) była istotnie mniejsza w grupach MOS-0.2 i MOS-0.4. Dodatek mannanu do diety spowodował zmniejszenie aktywności glikolitycznej mikroflory jelit ślepych indyków. Korzystne obniżenie aktywności $\beta$-glukuronidazy w treści jelit stwierdzono jedynie przy największej ilości MOS w diecie. 